\title{
Morphological Classification of Extraction Sockets and Clinical Decision Tree for Socket Preservation/Augmentation after Tooth Extraction: a Systematic Review
}

\author{
Gintaras Juodzbalys ${ }^{1}$, Arturas Stumbras', Samir Goyushov'², Onurcem Duruel ${ }^{3}$, Tolga Fikret \\ Tözüm ${ }^{4}$
}

${ }^{1}$ Department of Oral and Maxillofacial Surgery, Faculty of Odontology, Medical Academy, Lithuanian University of Health Sciences, Kaunas, Lithuania.

${ }^{2}$ Department of Periodontology, Faculty of Dentistry, Istanbul Aydin University, Istanbul, Turkey.

${ }^{3}$ Department of Periodontology, Faculty of Dentistry, Hacettepe University, Ankara, Turkey.

${ }^{4}$ Department of Periodontics, College of Dentistry, University of Illinois at Chicago, Chicago, Illinois, USA.

\author{
Corresponding Author: \\ Arturas Stumbras \\ Department of Maxillofacial Surgery, Faculty of Odontology \\ Lithuanian University of Health Sciences \\ Eivenių g. 2, LT-50028, Kaunas \\ Lithuania \\ Phone: +37062666332 \\ E-mail: arturas.stu@gmail.com
}

\begin{abstract}
Objectives: The aim of present study was to review current literature concerning extraction socket classification immediately following tooth extraction and the rationales for socket preservation/augmentation procedures and with reference to it suggest novel clinical decision tree for extraction socket preservation/augmentation in aesthetic and non-aesthetic area.

Material and Methods: The search protocol used the electronic MEDLINE (PubMed) and EMBASE databases for articles published between January 12009 and May 1 2019. The search included only human studies published in English. Outcomes were the indications and reasons for socket preservation/augmentation and classification of extraction sockets.

Results: Ten studies fulfilled the inclusion criteria and were selected for the study. Although there are various types of extraction socket classifications none of them could completely evaluate all morphological parameters of alveolar ridge. Furthermore, present study revealed that indications for extraction socket preservation/augmentation have wider spectrum than socket morphology and are related to surrounding tissue anatomy or dental implantation operation indications and timing. Based on currently proposed extraction socket classifications and rationales, a novel decision tree for extraction socket preservation/ augmentation immediately after tooth extraction in aesthetic and non-aesthetic area was suggested.

Conclusions: The need of extraction socket preservation/augmentation immediately after tooth extraction should be determined by the aesthetic, functional and risk-related viewpoint. A novel clinical decision tree for extraction socket preservation/augmentation immediately after tooth extraction in aesthetic and non-aesthetic zones can be useful tool in socket preservation/augmentation procedures.
\end{abstract}

Keywords: alveolar ridge augmentation; bone remodeling; classification; tooth extraction; tooth socket.

Accepted for publication: 5 September 2019

To cite this article:

Juodzbalys G, Stumbras A, Goyushov S, Duruel O, Tözüm TF.

Morphological Classification of Extraction Sockets and Clinical Decision Tree for Socket Preservation/Augmentation after Tooth Extraction: a Systematic Review

J Oral Maxillofac Res 2019;10(3):e3

URL: http://www.ejomr.org/JOMR/archives/2019/3/e3/v10n3e3.pdf

doi: $10.5037 /$ jomr.2019.10303 


\section{INTRODUCTION}

Through the last decades, the success rate of dental implants has evolved from modest numbers to current high results [1,2]. Placement of dental implant to edentulous regions offer specific advantages over the tooth supported fixed dental prosthesis such as preservation of the alveolar bone, avoiding adjacent teeth restoration, better aesthetics and function $[3,4]$.

Extraction of the tooth is indicated when a tooth has nonrestorable condition or cannot be maintained in a long-term period in terms of function or aesthetics. The beginning of the post extraction socket healing process is clinically observed by clot formation and end up with epithelized closure over the bone filled socket [5-7]. The healing of the extraction site may preserve the original bone dimensions with uneventful bone formation. Unfortunately, in most cases, following the tooth extraction, alveolar bone of the socket undergoes a loss of bone of $50 \%$ in its width within the first year [7-10]. Radiographic studies showed that loss of alveolar ridge height largely happened within the first 90 days post extraction. Expected horizontal and vertical bone loss after six months following the tooth extraction are $29-63 \%$ and $11-22 \%$ respectively $[11,12]$. Furthermore, traumatizing of extraction socket bony walls during extraction or by some pathological conditions can also evoke adverse dimensional changes.

Bone loss after tooth extraction may lead to two main challenging situations: it can create an aesthetic problem around the fixed dental prosthesis resulting in soft tissue recession, or it can make the application of dental implant more challenging requiring guided bone regeneration.

To decrease post extraction alveolar bone resorption and/or restore damaged socket walls, various treatment protocols have been recommended to preserve/augment the ridge [13-16]. All existing socket preservation techniques may limit the severity of ridge resorption but not totally prevent it. According to current studies, immediate implant placement also can minimize resorption of fresh extraction sockets $[17,18]$. However, severe bone damage before or during tooth extraction may force the clinician to change the implant placement protocol from immediate to delayed protocol [19].

Whereas post extraction residual hard and soft tissue morphology plays a crucial role in aesthetic and functional outcomes of the future implant therapy, worldwide overview to extraction socket classification system allows clinicians to ease communication and data collection, which may lead to development of more predictable treatment modalities or to establish the most appropriate treatment plan after tooth extraction.

The aim of this study was to review current literature concerning extraction socket classification immediately following tooth extraction and the rationales for socket preservation/augmentation procedures and with reference to it suggest novel clinical decision tree for extraction socket preservation/augmentation in aesthetic and nonaesthetic areas to provide the practitioners planning dental implants with more accurate prognosis in all tooth regions.

\section{MATERIAL AND METHODS Protocol and registration}

The methods of the analysis and inclusion criteria were specified in advance and documented in a protocol. The review was registered in PROSPERO, an international prospective register of systematic reviews. Registration number: CRD42019136314.

The protocol can be accessed at:

https://www.crd.york.ac.uk/PROSPERO/display record.php?RecordID=136314.

The reporting of this systematic analysis adhered to the Preferred Reporting Items for Systematic Review and Meta-Analysis (PRISMA) Statement [미].

\section{Focus question}

The following focus question was developed according to the problem, intervention, comparison, and outcome (PICO) study design (Table 1):

What are the indications for socket preservation/ augmentation procedures based on separate clinical and radiographic extraction socket parameters or organized into classification system, in aesthetic and non-aesthetic zones immediately after tooth extraction?

\section{Information sources}

An electronic search was performed for articles in English language published from January 12009 and May 1 2019, by two reviewers (OD and SG) using MEDLINE (PubMed) and EMBASE databases. Reference lists of studies were also hand-searched for relevance.

\section{Search}

The search strategy incorporated the examination of 
Table 1. The focus question development according to the PICOS study design

\begin{tabular}{l|l}
\hline \multicolumn{1}{c|}{ Component } & \multicolumn{1}{c}{ Description } \\
\hline Problem (P) & Non-standardize extraction sockets \\
\hline Intervention (I) & A simple decision tree of indications and reasons for socket augmentation \\
\hline Comparison (C) & Comparison of extraction sockets based on preservation/augmentation necessity \\
\hline Outcome (O) & No decision tree for socket preservation/augmentation necessity in aesthetic zone was found \\
\hline Study design (S) & Randomized controlled trial \\
\hline Focus question & $\begin{array}{l}\text { What are the indications for socket preservation/augmentation procedures based on separate clinical } \\
\text { and radiographic extraction socket parameters or organized into classification system, in aesthetic } \\
\text { and non-aesthetic zones immediately after tooth extraction? }\end{array}$ \\
\hline
\end{tabular}

MEDLINE (PubMed) and EMBASE electronic databases. The following keywords were used: "socket augmentation" OR "socket preservation" OR "socket augmentation necessity" OR "socket augmentation indication" OR "extraction socket classification".

\section{Selection of studies}

The included articles were selected by OD and SG according to inclusion and exclusion criteria. Any disagreement was resolved through discussion. In addition, an experienced senior reviewer consulted the included articles (Figure 1).

\section{Types of publications}

The review included only human studies published in English. Letters, editorials, PhD theses, and abstracts, in vitro and animal studies were excluded.

\section{Types of studies}

This present review included all human prospective, follow-up studies, clinical trials, cohort studies, case-control studies, systematic reviews/guidelines of consensus conferences in the English language published from January 12009 and May 12019.

\section{Types of participants/population}

Subjects, whose extraction sockets' dimensional changes were evaluated by the clinical and/or radiological parameters, were included in this present review.

\section{Inclusion and exclusion criteria}

The applied inclusion criteria were as follows:

- Studies analysing the indications and reasons for socket preservation/augmentation procedures depending on extraction sockets morphology conditions immediately following tooth extraction, in aesthetic and non-aesthetic zones;

- Articles, proposing classification for extraction sockets based on the clinical and/or radiological parameters immediately following tooth extraction.

The following types of articles were excluded as follows:

- Letters, editorials, $\mathrm{PhD}$ theses, and abstracts, in vitro and animal studies;

- Studies not focused specifically on the selected topic.

\section{Sequential search strategy}

While initial literature search, all articles were selected based on titles and abstracts. Two independent reviewers (OD and SG) selected the included articles according to inclusion and exclusion criteria. An experienced senior reviewer consulted the included articles for the final stage of screening.

\section{Data extraction}

The data were independently extracted from included articles according to aims and themes of this review.

\section{Data items}

Data were collected and arranged from selected articles in the following fields:

- "Year" - describes the date of publication.

- "Type of study" - indicates the type of study.

- "Extraction socket classification" - describes the morphology of extraction socket.

- "Extraction socket preservation" - describes a procedure to reduce alveolar bone loss after tooth extraction.

- "Extraction socket augmentation" - describes a procedure to restore damaged extraction socket tissues after tooth extraction. 


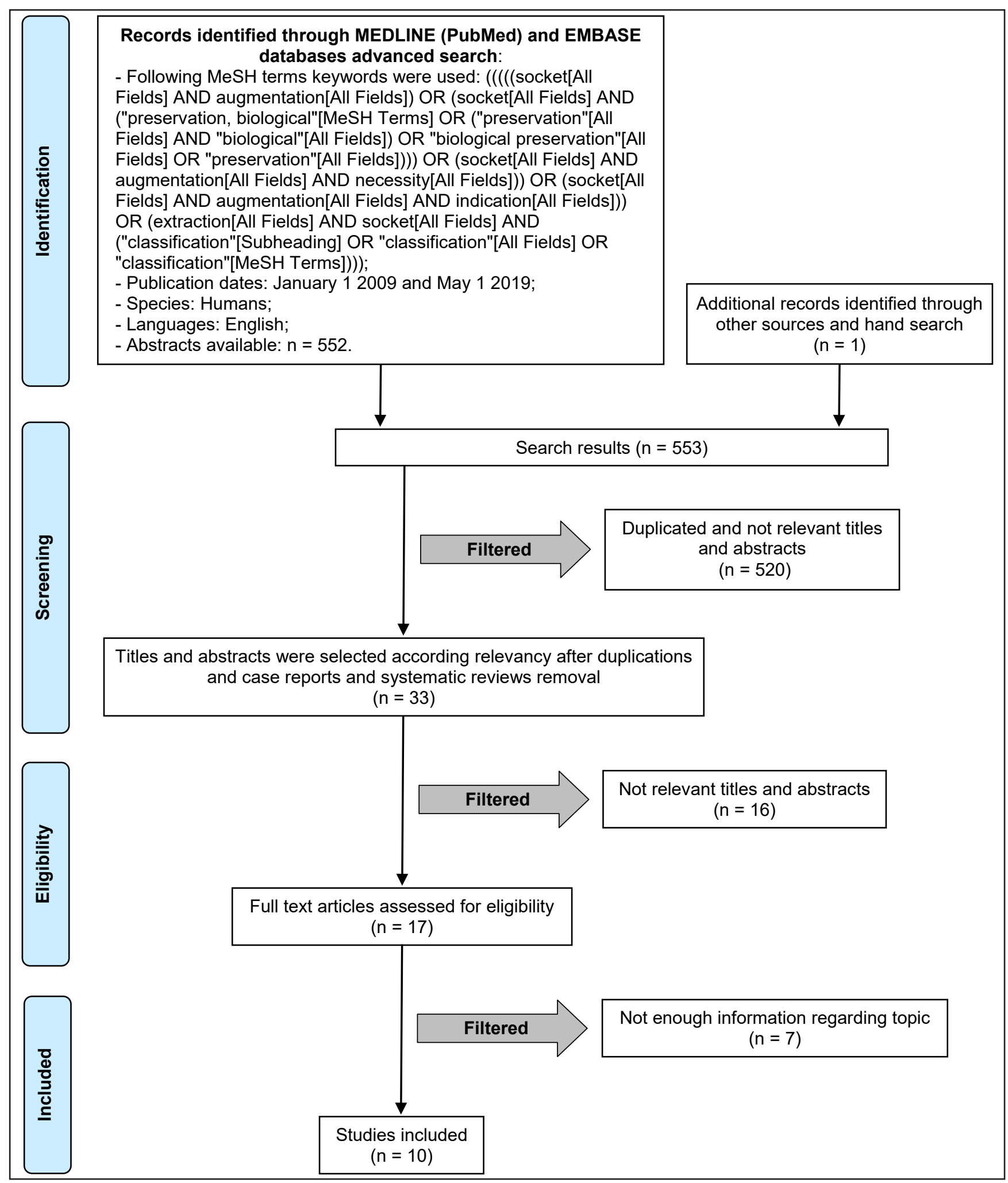

Figure 1. Flowchart of literature search and selection process.

- "Clinical parameters" - revealed what clinical parameters authors suggests to evaluate for extraction socket preservation/augmentation.

- "Radiologic parameters" - revealed what radiologic parameters authors suggests to evaluate for extraction socket preservation/ augmentation.

\section{Risk of bias within studies}

The methodological quality of each study was performed by using the risk of bias assessment tool outlined in Cochrane Handbook for Systematic Reviews of Interventions [21]. Seven domains were evaluated random sequence generation, 
allocation concealment, defined inclusion/exclusion, blinding of participants and/or personnel, blinding of outcome assessment, incomplete outcome data and selective reporting. Absence of information regarding blinding was not treated as relative because it could not have any effect for the study.

\section{Statistical analysis}

Heterogeneity between studies was found therefore meta-analysis could not be performed.

\section{RESULTS}

\section{Study selection}

Article review and data extraction were performed according to the PRISMA flow diagram (Figure 1). The initial search displayed 553 results from the MEDLINE (NCBI Ovid and PubMed Central [PMC]) and EMBASE databases. The inclusion and exclusion criteria were applied to 536 articles. After inclusion and exclusion criteria were applied, 17 articles were selected. Finally, 10 full text articles were included in this study.

\section{Study exclusion}

The reasons for excluding were as follows: animal studies $(n=3)[11, \underline{22}, \underline{23}]$, being a case studies $(n=1)$ [24] and not enough information regarding the topic $(\mathrm{n}=3)$ [25-27].

\section{Quality assessment of the included studies}

Only six studies of the included papers were clinical studies. Quality and risk assessment was conducted by one author (AS) and is represented in Table 2. Included studies were assessed following the Cochrane collaboration's tool [21] for assessing risk of bias. Summarizing, no single study was classified as low risk of bias for all the criteria and most studies demonstrated moderate or unclear risk of bias.

\section{Extraction socket classifications}

There have been several proposed systems to extraction socket classification. All included articles are summarized in Table 3. Caplanis et al. [28] introduced a new classification in 2004,

Table 2. Assessment of the risk of bias

\begin{tabular}{l|c|c|c|c|c|c|c|c}
\hline \multicolumn{1}{c|}{ Study } & $\begin{array}{c}\text { Year of } \\
\text { publication }\end{array}$ & $\begin{array}{c}\text { Random } \\
\text { sequence } \\
\text { generation }\end{array}$ & $\begin{array}{c}\text { Allocation } \\
\text { concealment }\end{array}$ & $\begin{array}{c}\text { Defined } \\
\text { inclusion/ } \\
\text { exclusion }\end{array}$ & $\begin{array}{c}\text { Blinding of } \\
\text { participants and/ } \\
\text { or personnel }\end{array}$ & $\begin{array}{c}\text { Blinding of } \\
\text { outcome } \\
\text { assessment }\end{array}$ & $\begin{array}{c}\text { Incomplete } \\
\text { outcome } \\
\text { data }\end{array}$ & $\begin{array}{c}\text { Selective } \\
\text { reporting }\end{array}$ \\
\hline Juodzbalys et al. [30] & 2008 & N/A & N/A & + & N/A & N/A & + & + \\
\hline Schlee et al. [33] & 2009 & + & + & + & N/A & N/A & + & + \\
\hline Horowitz et al. [34] & 2009 & N/A & N/A & + & N/A & N/A & + & + \\
\hline Jung et al. [35] & 2018 & - & - & + & N/A & N/A & + & + \\
\hline Kim et al. [62] & 2017 & N/A & N/A & + & N/A & N/A & + & + \\
\hline
\end{tabular}

$+=$ low risk; $\mathrm{N} / \mathrm{A}=$ unclear risk; - = high risk.

Table 3. The description of extraction socket classifications in included studies

\begin{tabular}{l|c|c|c|c}
\hline \multicolumn{1}{c|}{ Study } & $\begin{array}{c}\text { Year of } \\
\text { publication }\end{array}$ & Hard tissue parameters & Soft tissue parameters & $\begin{array}{c}\text { Methods of assess- } \\
\text { ment }\end{array}$ \\
\hline Smith and Tarnow [19] & 2013 & $\begin{array}{c}\text { Immediately placed dental implant's } \\
\text { coverage by septal bone }\end{array}$ & N/R & N/R \\
\hline Caplanis et al. [28] & 2005 & $\begin{array}{c}\text { Affected socket walls, amount of bone } \\
\text { loss, distance between alveolar crest and } \\
\text { dentinoenamel junction }\end{array}$ & Periodontal biotype & Surgical template \\
\hline Elian et al. [29] & 2007 & Buccal bone level & Facial soft tissue level & N/R \\
\hline Juodzbalys et al. [30] & 2008 & $\begin{array}{c}\text { Alveolar process height, bone beyond } \\
\text { the apex, labial bone vertical position, } \\
\text { buccal bone thickness, presence of lesion, } \\
\text { intradental bone peak height, mesiodistal } \\
\text { distance, palatal angulation necessity }\end{array}$ & $\begin{array}{c}\text { Soft tissue contour, soft tissue } \\
\text { vertical deficiency, keratinized } \\
\text { gingiva width, papillae } \\
\text { appearance, soft tissue colour, } \\
\text { consistency, gingival biotype }\end{array}$ & $\begin{array}{c}\text { Radiographic, visual } \\
\text { valuation and socket } \\
\text { sounding using peri- } \\
\text { odontal probe }\end{array}$ \\
\hline Chu et al. [31] & 2015 & Buccal bone plate level & Buccal soft tissue deficiency & N/R \\
\hline El Chaar et al. [32] & 2016 & $\begin{array}{c}\text { Buccal plate loss, periapical bone } \\
\text { topography, interproximal bone level }\end{array}$ & Soft tissue biotype & N/R \\
\hline
\end{tabular}

$\mathrm{N} / \mathrm{R}=$ data not reported 
which comprised general assessments of hard and soft tissue walls of socket. After the detailed socket evaluation studies, it has become noticeable to the authors that the quality and quantity of the buccal hard tissue is key factor in a long-term healing. In 2007, Elian et al. [29] proposed more simplified extraction socket classification and rationale for socket preservation for the aesthetic region. The classification was based on buccal bone and soft tissue level. Another classification and treatment recommendation of extraction defect suggested by Juodzbalys et al. [30] which was based upon both the hard and soft tissues. Authors proposed extraction socket classification encompassed not only quantitative measurements of hard and soft tissue but also included qualitative parameters of it. Another classification system for posterior teeth extraction socket in terms of septum bone morphology proposed in 2013 [19]. This molars extraction sites classification is based upon the available septum bone for stabilization of immediately placed implant. Meanwhile Chu et al. [31] subclassified previously reported extraction socket classification [29] and comprised extraction sites with bone defect. Extraction socket classification performed by El Chaar et al. [32] subclassified extraction socket in accordance with buccal bone plate loss, interproximal bone height, apical topography and soft tissue biotype.

\section{Indications and reasons for extraction socket preservation/augmentation}

Detailed literature scanning showed very little existing accurate knowledge about the indications for extraction socket preservation. Indications for soft tissue grafting after tooth extraction was evaluated by Schlee et al. [33] and decision tree was suggested. Connective tissue grafts were recommended after the assessment of gingival biotype of the extraction site. A study performed by Horowitz et al. [34] showed that extraction socket preservation resulted in more reduced bone resorption compare to dimensional alveolar bone changes after immediate implant placement. Recently, Jung et al. [35] described all treatment modalities, their limitations and presented a valuable decision tree for alveolar ridge preservation in aesthetic zone.

\section{DISCUSSION}

Extraction socket preservation is defined as alveolar ridge preservation within the bone envelope remaining after tooth extraction, meanwhile ridge augmentation is defined as increasing the volume of alveolar ridge beyond the bony envelope at the time of tooth extraction [26]. In clinical practice sometimes it is difficult to separate those two procedures and in literature they are described mainly as extraction socket preservation. In present study authors' opinion those definitions should be revised and discussed, because it is impossible to preserve not existing damaged socket structures. Definition "extraction socket preservation" is recommended to use in cases where extraction socket anatomy is intact. In contrast definition "extraction socket augmentation" defines alveolar ridge restoration when bony walls of the socket are partly or completely lost. Taking into account fact, that different definitions can cause misunderstandings in present study both definitions were used.

The tooth extraction generally results in some morphological and compositional modifications in the overlying soft tissue of the socket [36]. Threedimensionally soft tissue changes are expectable both vertically and horizontally immediately after extraction [37]. The quality and quantity of periimplant soft tissue plays an important role in achieving an aesthetically acceptable outcome of implant-supported prosthesis. Another crucial factor in achieving aesthetic peri-implant soft tissue after applying final prosthesis is biological width. It is obvious that insufficient peri-implant soft tissue can cause deficiencies in terms of peri-implant aesthetic appearance [38]. Different surgical approaches have been suggested to overcome these situations following implant therapy and to enhance aesthetic outcomes of peri-implant soft tissues $[\underline{39}, \underline{40}]$. The connective tissue graft performing in conjunction to immediate implantation have been proposed by various authors [40-43]. Some authors in clinical cases with both soft and hard tissue defects proposed extraction socket augmentation with bone graft substitute placed at the bony level and autologous soft-tissue graft or soft-tissue substitute placed at the level of adjacent soft tissue [44-47]. Jung et al. [44] combining demineralized bovine bone mineral with collagen membrane or autogenous soft tissue graft resulted in significantly reduced horizontal and vertical alveolar resorption compare to spontaneous healing.

It has been suggested that the bone walls of the extraction socket may be preserved by immediate implant placement $[17,18]$. However, according to animal studies the buccal wall of the socket undergo significant resorption which could not be prevented by immediate implantation $[\underline{7}, \underline{10}]$. Horowitz et al. [34] observed more favourable results after socket preservation compare to site collapse after immediate 
implant placement. The study comparing alveolar ridge dimensional changes after immediately placed implants with or without additional bone regeneration procedures demonstrated horizontal bone resorption $43.3 \%$ in the group without grafting material and only $15.8 \%$ in the group with simultaneous bone regeneration procedure [48]. Some studies suggest the minimal buccal bone thickness $(2 \mathrm{~mm})$ to maintain the facial aspect of the implant [49-51]. When the buccal bone plate is thin or is dehisced, it is more likely to increased resorption and greater alveolar ridge alterations following tooth extraction [52]. In these types of cases immediate implant placement is not possible without decreased primary implant stability or implant body exposure. The correlation between buccal bone thickness and alveolar ridge dimensional changes were observed by Jung et al. [53] and resulted in more pronounced bone resorption in cases with thin buccal bone plate. However, the same study demonstrated that extraction socket preservation prevented from bone remodelling even in sites with less than $1 \mathrm{~mm}$ of buccal bone thickness.

Following the atraumatic tooth extraction, detailed evaluation of the socket bony walls is initially made by bone probing technique. Appreciation of the remaining socket walls and their post extraction conditions is crucial for choosing of the implant treatment protocol [28]. Alveolar ridge preservation procedure has been suggested in cases with severe loss of buccal bone plate $(>50 \%)$ [48]. Patients with thin soft tissue biotype and buccal bone loss from $25 \%$ to $50 \%$ a delayed implant placement with socket preservation is recommended [32]. The horizontal bone loss of the socket walls is evaluated: the distance between the tip of the socket labial plate and coronal border of the buccal bone of adjacent regions. Acceptable distance for immediate implant placement is estimated to be $2 \mathrm{~mm}$ [28].

For immediate implant placement protocol, contribution of the apical bone is clinically vital to ensure not only favourable implantation but also to attain sufficient primary implant stability. Several authors suggested at least $3-5 \mathrm{~mm}$ of periapical intact bone for an intimate bone-to-implant contact [19]. However, it is important to understand and evaluate the anatomy of the region through cone-beam computed tomography for avoiding injuries to the crucial adjacent landmarks [54]. The inferior alveolar nerve, the incisive canal, the mental foramen, nasal floor, and maxillary sinus are the most common adjacent vital anatomical structures, which should be examined thoroughly before the implant surgery $[\underline{55}, \underline{56}]$.

The septal bone of the posterior tooth socket is the primary available bone area for immediate implant placement. Therefore, during the multi-rooted tooth extraction, special care should be taken not to compress or damage the interdental septum. In the sockets with impaired septum bone, primary stability of the implant is achieved by the walls of the socket. Therefore, in this type of sockets buccal bone plate should be thick and intact thus wider implants could be placed [19].

The evident advantage of the immediate implantation is reduced treatment time. Immediate implantation is a well-accepted treatment protocol because of the obvious advantages such as; reduced treatment time, extraction socket walls maintenance, and attaining better aesthetic results. However, applying immediate implant placement protocol to the socket with periapical pathology is a matter of debate. The possible complication of this technique might be the microbial contamination of the socket during the initial phase of healing [57,58]. There are several clinical studies which support the high survival rate and normal osseointegration when implants are placed immediately after extraction of teeth presenting endodontic lesions [59-61]. Considering the risk of apical peri-implantitis or even implant failure attention should be focused on alveolar debridement and meticulous cleansing of extraction socket before implant placement and using medications including a bactericide antibiotic and anti-inflammatory analgesics. Meanwhile, a study performed by Kim et al. [62] analysed ridge augmentation in periodontally compromised extraction sockets and resulted in $99.3 \%$ safety rate after thorough extraction of infectious source.

The pneumatization of the maxillary sinus is a physiological process that occurs during the growth period, causing to the volume increasing [63]. The apices of the maxillary posterior teeth are inserted within the maxillary sinus cavity in some cases, which could jeopardize the implant insertion [64]. Immediate implant placement is not recommended in these situations without sinus lifting surgery. There have been suggested different sinus augmentation procedures that are performed at the time of dental extraction [65-67].

The study by Al-Hezaimi et al. [22] reported that buccal bone gets blood supply from adjacent teeth and classified extraction socket as a single tooth extraction or multiple teeth extraction. This was in agreement with a study performed by Al-Asker et al. [68] who reported that contiguous tooth extraction resulted in more pronounced alveolar bone loss. The correlation between bone loss and immediate placed implants were more extensive in multiple adjacent teeth extraction [23]. 
Table 4. The clinical decision tree for extraction socket preservation/augmentation

\begin{tabular}{|c|c|c|}
\hline $\begin{array}{c}\text { Indications and reasons for extraction socket preservation/ } \\
\text { augmentation }\end{array}$ & Aesthetic zone & Non aesthetic zone \\
\hline \multicolumn{3}{|l|}{ Aesthetic } \\
\hline \multirow{3}{*}{ Impossible to reach sufficient aesthetic result } & \multicolumn{2}{|c|}{ Facial soft tissue deficiency of extraction socket } \\
\hline & $\begin{array}{c}\text { Absence of buccal wall of extraction } \\
\text { socket }>50 \%\end{array}$ & $\begin{array}{c}\text { Absence of buccal wall of } \\
\text { extraction socket }\end{array}$ \\
\hline & Horizontal bone loss $>2 \mathrm{~mm}$ & Horizontal bone loss $>3 \mathrm{~mm}$ \\
\hline \multicolumn{3}{|l|}{ Functional } \\
\hline Impossible to gain implant primary stability & $\begin{array}{c}\text { Available bone beyond the apex of } \\
\text { extraction socket }<3 \mathrm{~mm} \text { and absence } \\
\text { of implant to bony walls contact }\end{array}$ & $\begin{array}{c}\text { Available bone beyond the } \\
\text { apex of extraction socket }<3 \\
\text { mm and absence of septal bone }\end{array}$ \\
\hline \multicolumn{3}{|l|}{ Risk related } \\
\hline \multirow[t]{2}{*}{ Risk of significant alveolar bone resorption } & \multicolumn{2}{|c|}{$\begin{array}{l}\text { Multiple extractions when buccal extraction socket wall thickness } \\
\qquad<2 \mathrm{~mm} \text { and thin }(<1 \mathrm{~mm}) \text { biotype }\end{array}$} \\
\hline & \multicolumn{2}{|c|}{ Postponed or not recommended implantation for some reasons } \\
\hline Risk of apical peri-implantitis development & \multicolumn{2}{|c|}{ Presence of extraction socket bone lesions $>5 \mathrm{~mm}$} \\
\hline $\begin{array}{l}\text { Risk of maxillary sinus perforation and reducing the need for } \\
\text { elevation of the sinus floor }\end{array}$ & \multicolumn{2}{|c|}{ Presence of roots penetrating into maxillary sinus } \\
\hline $\begin{array}{l}\text { Risk of nasal floor perforation and reducing the need for elevation } \\
\text { of the nasal floor }\end{array}$ & \multicolumn{2}{|c|}{ Presence maxillary alveolar process atrophy in nasal floor projection } \\
\hline
\end{tabular}

For better identification of the socket status, thoroughly evaluation of the soft and hard tissue around the socket should be performed immediately after tooth extraction. Although there are various types of extraction socket classifications none of them could completely evaluate all morphological parameters of alveolar ridge. Furthermore, present study revealed that indications for extraction socket preservation have wider spectrum than socket morphology and are related to surrounding tissue anatomy or dental implantation operation indications and timing. Taking on account results of analysis of extraction socket classifications and rationales for alveolar ridge preservation we suggested a decision tree for extraction socket augmentation/preservation immediately after tooth extraction in aesthetic and non-aesthetic zones (Table 4).

Indications and reasons for extraction socket preservation/augmentation were subclassified to aesthetic, when impossible to reach sufficient aesthetic result; functional, when impossible to gain implant primary stability; and risk related, when there is possibility of significant alveolar bone resorption, apical peri-implantitis development, and maxillary sinus as well as nasal floor perforation or possibility to reduce need for elevation of the sinus and nasal floor. Different parameters are determined for aesthetic and non-aesthetic zones.

However, this article has some limitations. The clinical decision tree for extraction socket preservation/augmentation is mostly based on bone morphology and its relation with vital structures. Indications do not include detailed soft tissue assessment because it was described by the authors of previous extraction socket classification [48].
Moreover, when interpreting the results of the study, including only human studies and not performing statistical analysis should be taken into consideration as limitations. Since novel clinical decision tree for extraction socket preservation/augmentation in aesthetic and non-aesthetic zones is based on comprehensive indications, authors believe that it can be useful tool to the clinician establishing the most appropriate treatment plan after tooth extraction.

\section{CONCLUSIONS}

A novel clinical decision tree for extraction socket preservation/augmentation immediately after tooth extraction in aesthetic and non-aesthetic zones has been presented. The proposed indications help to determine the need of extraction socket preservation/ augmentation from the aesthetic, functional and riskrelated viewpoint. However, thorough clinical and radiographic evaluation of extraction socket should be performed. Based on current evidence, extraction socket preservation/augmentation is suggested not only in clinical cases with dental implants being planned but also to preserve alveolar bone for removable prosthesis fixation or to support soft tissue around fixed dental prosthesis. Further studies are needed to validate the reliability of proposed clinical decision tree for extraction socket augmentation.

\section{ACKNOWLEDGMENTS AND DISCLOSURE STATEMENTS}

The authors report no conflicts of interest related to this study. 


\section{REFERENCES}

1. Karoussis IK, Salvi GE, Heitz-Mayfield LJ, Brägger U, Hämmerle CH, Lang NP. Long-term implant prognosis in patients with and without a history of chronic periodontitis: a 10-year prospective cohort study of the ITI Dental Implant System. Clin Oral Implants Res. 2003 Jun;14(3):329-39. [Medline: 12755783] [doi: 10.1034/j.1600-0501.000.00934.x]

2. Romeo E, Lops D, Margutti E, Ghisolfi M, Chiapasco M, Vogel G. Long-term survival and success of oral implants in the treatment of full and partial arches: a 7-year prospective study with the ITI dental implant system. Int J Oral Maxillofac Implants. 2004 Mar-Apr;19(2):247-59. [Medline: 15101597]

3. Reikie DF. Esthetic and functional considerations for implant restoration of the partially edentulous patient. J Prosthet Dent. 1993 Nov;70(5):433-7. [Medline: 8254546] [doi: 10.1016/0022-3913(93)90080-8]

4. Garber DA. The esthetic dental implant: letting restoration be the guide. J Oral Implantol. 1996;22(1):45-50. [Medline: $\underline{8957890]}$

5. Amler MH. The time sequence of tissue regeneration in human extraction wounds. Oral Surg Oral Med Oral Pathol. 1969 Mar;27(3):309-18. [Medline: 5251474] [doi: 10.1016/0030-4220(69)90357-0]

6. Cardaropoli G, Araújo M, Lindhe J. Dynamics of bone tissue formation in tooth extraction sites. An experimental study in dogs. J Clin Periodontol. 2003 Sep;30(9):809-18. [Medline: 12956657] [doi: 10.1034/j.1600-051X.2003.00366.x]

7. Araújo MG, Lindhe J. Dimensional ridge alterations following tooth extraction. An experimental study in the dog. J Clin Periodontol. 2005 Feb;32(2):212-8. [Medline: 15691354] [doi: 10.1111/j.1600-051X.2005.00642.x]

8. Johnson K. A study of the dimensional changes occurring in the maxilla following tooth extraction. Aust Dent J. 1969 Aug;14(4):241-4. [Medline: 5259350] [doi: 10.1111/j.1834-7819.1969.tb06001.x]

9. Araújo MG, Lindhe J. Ridge alterations following tooth extraction with and without flap elevation: an experimental study in the dog. Clin Oral Implants Res. 2009 Jun;20(6):545-9. [Medline: 19515033] [doi: 10.1111/j.1600-0501.2008.01703.x]

10. Cardaropoli G, Araújo M, Hayacibara R, Sukekava F, Lindhe J. Healing of extraction sockets and surgically produced augmented and non-augmented - defects in the alveolar ridge. An experimental study in the dog. J Clin Periodontol. 2005 May;32(5):435-40. [Medline: 15842256] [doi: 10.1111/j.1600-051X.2005.00692.x]

11. Fickl, S., et al., Tissue alterations after tooth extraction with and without surgical trauma: a volumetric Fickl S, Zuhr O, Wachtel H, Bolz W, Huerzeler M. Tissue alterations after tooth extraction with and without surgical trauma: a volumetric study in the beagle dog. J Clin Periodontol. 2008 Apr;35(4):356-63. [Medline: 18353082] [doi: 10.1111/j.1600-051X.2008.01209.x]

12. Schropp L, Wenzel A, Kostopoulos L, Karring T. Bone healing and soft tissue contour changes following singletooth extraction: a clinical and radiographic 12-month prospective study. Int J Periodontics Restorative Dent. 2003 Aug;23(4):313-23. [Medline: 12956475]

13. Ross SE, Strauss T, Crossetti HW, Gargiulo AW. The immediate placement of an endosseous implant into an extraction wound: a clinical case report using the RosTR System. Int J Periodontics Restorative Dent. 1989;9(1):34-41. [Medline: 2599780]

14. Gelb DA. Immediate implant surgery: three-year retrospective evaluation of 50 consecutive cases. Int J Oral Maxillofac Implants. 1993;8(4):388-99. [Medline: 8270307$]$

15. Garber DA, Belser UC. Restoration-driven implant placement with restoration-generated site development. Compend Contin Educ Dent. 1995 Aug;16(8):796, 798-802, 804. [Medline: 8620398]

16. Becker W, Dahlin C, Becker BE, Lekholm U, van Steenberghe D, Higuchi K, Kultje C. The use of e-PTFE barrier membranes for bone promotion around titanium implants placed into extraction sockets: a prospective multicenter study. Int J Oral Maxillofac Implants. 1994 Jan-Feb;9(1):31-40. [Medline: $\underline{8150510]}$

17. Brugnami F, Then PR, Moroi H, Kabani S, Leone CW. GBR in human extraction sockets and ridge defects prior to implant placement: clinical results and histologic evidence of osteoblastic and osteoclastic activities in DFDBA. Int J Periodontics Restorative Dent. 1999 Jun;19(3):259-67. [Medline: 10635172]

18. Lazzara RJ. Immediate implant placement into extraction sites: surgical and restorative advantages. Int J Periodontics Restorative Dent. 1989;9(5):332-43. [Medline: 2640210]

19. Smith RB, Tarnow DP. Classification of molar extraction sites for immediate dental implant placement: technical note. Int J Oral Maxillofac Implants. 2013 May-Jun;28(3):911-6 [Medline: 23748327] [doi: 10.11607/jomi.2627]

20. Moher D, Liberati A, Tetzlaff J, Altman DG; PRISMA Group. Preferred reporting items for systematic reviews and meta-analyses: the PRISMA statement. J Clin Epidemiol. 2009 Oct;62(10):1006-12. [Medline: 19631508] [doi: $10.1016 /$ j.jclinepi.2009.06.005]

21. Higgins JPT, Green S. Cochrane Handbook for Systematic Reviews of Interventions version 5.1.0. The Cochrane Collaboration, 2011. [URL: http://training.cochrane.org/handbook]

22. Al-Hezaimi K, Levi P, Rudy R, Al-Jandan B, Al-Rasheed A. An extraction socket classification developed using analysis of bone type and blood supply to the buccal bone in monkeys. Int J Periodontics Restorative Dent. 2011 Jul-Aug;31(4):421-7. [Medline: 21837308]

23. Al-Shabeeb MS, Al-Askar M, Al-Rasheed A, Babay N, Javed F, Wang HL, Al-Hezaimi K. Alveolar bone remodeling around immediate implants placed in accordance with the extraction socket classification: a three-dimensional microcomputed tomography analysis. J Periodontol. 2012 Aug;83(8):981-7. [Medline: 22166163] [doi: 10.1902/jop.2011.110569] 
24. Wang HL, Tsao YP. Mineralized bone allograft-plug socket augmentation: rationale and technique. Implant Dent. 2007 Mar;16(1):33-41. [Medline: 17356370] [doi: 10.1097/ID.0b013e318031ece6]

25. Agbaje JO, Jacobs R, Maes F, Michiels K, van Steenberghe D. Volumetric analysis of extraction sockets using cone beam computed tomography: a pilot study on ex vivo jaw bone. J Clin Periodontol. 2007 Nov;34(11):985-90. [Medline: 17935503] [doi: 10.1111/j.1600-051X.2007.01134.x]

26. Hämmerle $\mathrm{CH}$, Araújo MG, Simion M; Osteology Consensus Group 2011. Evidence-based knowledge on the biology and treatment of extraction sockets. Clin Oral Implants Res. 2012 Feb;23 Suppl 5:80-2. [Medline: 22211307] [doi: 10.1111/j.1600-0501.2011.02370.x]

27. Clementini M, Tiravia L, De Risi V, Vittorini Orgeas G, Mannocci A, de Sanctis M. Dimensional changes after immediate implant placement with or without simultaneous regenerative procedures: a systematic review and meta-analysis. |J Clin Periodontol. 2015 Jul;42(7):666-77. [Medline: 26073267] [doi: 10.1111/jcpe.12423]

28. Caplanis N, Lozada JL, Kan JY. Extraction defect assessment, classification, and management. J Calif Dent Assoc. 2005 Nov;33(11):853-63. [Medline: 16463907]

29. Elian N, Cho SC, Froum S, Smith RB, Tarnow DP. A simplified socket classification and repair technique. Pract Proced Aesthet Dent. 2007 Mar;19(2):99-104; quiz 106. [Medline: 17491484]

30. Juodzbalys G, Sakavicius D, Wang HL. Classification of extraction sockets based upon soft and hard tissue components. J Periodontol. 2008 Mar;79(3):413-24. [Medline: 18315423] [doi: 10.1902/jop.2008.070397]

31. Chu SJ, Sarnachiaro GO, Hochman MN, Tarnow DP. Subclassification and Clinical Management of Extraction Sockets with Labial Dentoalveolar Dehiscence Defects. Compend Contin Educ Dent. 2015 Jul-Aug;36(7):516, 518-20, 522 passim. [Medline: 26247445]

32. El Chaar E, Oshman S, Fallah Abed P. Single-Rooted Extraction Sockets: Classification and Treatment Protocol. Compend Contin Educ Dent. 2016 Sep;37(8):537-541;quiz542. [Medline: 27608197]

33. Schlee M, Esposito M. Aesthetic and patient preference using a bone substitute to preserve extraction sockets under pontics. A cross-sectional survey. Eur J Oral Implantol. 2009 Autumn;2(3):209-17. [Medline: 20467631]

34. Horowitz RA, Mazor Z, Miller RJ, Krauser J, Prasad HS, Rohrer MD. Clinical evaluation alveolar ridge preservation with a beta-tricalcium phosphate socket graft. Compend Contin Educ Dent. 2009 Nov-Dec;30(9):588-90, 592, 594 passim; quiz 604, 606. [Medline: 19998726]

35. Jung RE, Ioannidis A, Hämmerle CHF, Thoma DS. Alveolar ridge preservation in the esthetic zone. Periodontol 2000. 2018 Jun;77(1):165-175. [Medline: 29484712] [doi: 10.1111/prd.12209]

36. Bays R. Pathophysiology and anatomy of edentulous bone loss. In: Fonseca RJ, Davis WH, editors. Reconstructive preprosthetic oral and maxillofacial surgery. Philadelphia: Saunders; 1986. p. 1-17.

37. Mecall RA, Rosenfeld AL. Influence of residual ridge resorption patterns on fixture placement and tooth position, Part III: Presurgical assessment of ridge augmentation requirements. Int J Periodontics Restorative Dent. 1996 Aug;16(4):322-37. [Medline: $\underline{9242100]}$

38. Schneider D, Grunder U, Ender A, Hämmerle CH, Jung RE. Volume gain and stability of peri-implant tissue following bone and soft tissue augmentation: 1-year results from a prospective cohort study. Clin Oral Implants Res. 2011 Jan;22(1): 28-37. [Medline: 21039891] [doi: 10.1111/j.1600-0501.2010.01987.x]

39. Cosyn J, Hooghe N, De Bruyn H. A systematic review on the frequency of advanced recession following single immediate implant treatment. J Clin Periodontol. 2012 Jun;39(6):582-9. [Medline: 22509794] [doi: 10.1111/j.1600-051X.2012.01888.x]

40. Kan JY, Rungcharassaeng K, Lozada JL, Zimmerman G. Facial gingival tissue stability following immediate placement and provisionalization of maxillary anterior single implants: a 2- to 8-year follow-up. Int J Oral Maxillofac Implants. 2011 Jan-Feb;26(1):179-87. [Medline: 21365054]

41. Barone R, Clauser C, Grassi R, Merli M, Prato GP. A protocol for maintaining or increasing the width of masticatory mucosa around submerged implants: a 1-year prospective study on 53 patients. Int J Periodontics Restorative Dent. 1998 Aug;18(4):377-87. [Medline: 12693424]

42. Landi L, Sabatucci D. Plastic surgery at the time of membrane removal around mandibular endosseous implants: a modified technique for implant uncovering. Int J Periodontics Restorative Dent. 2001 Jun;21(3):280-7. [Medline: 11490405]

43. Tinti C, Benfenati SP. The ramp mattress suture: a new suturing technique combined with a surgical procedure to obtain papillae between implants in the buccal area. Int J Periodontics Restorative Dent. 2002 Feb;22(1):63-9. [Medline: $\underline{11922220]}$

44. Jung RE, Philipp A, Annen BM, Signorelli L, Thoma DS, Hämmerle CH, Attin T, Schmidlin P. Radiographic evaluation of different techniques for ridge preservation after tooth extraction: a randomized controlled clinical trial. J Clin Periodontol. 2013 Jan;40(1):90-8. [Medline: 23163915] [doi: 10.1111/jcpe.12027]

45. Lindhe J, Cecchinato D, Donati M, Tomasi C, Liljenberg B. Ridge preservation with the use of deproteinized bovine bone mineral. Clin Oral Implants Res. 2014 Jul;25(7):786-90. [Medline: 23556467] [doi: 10.1111/clr.12170]

46. Mardinger $\mathrm{O}$, Vered M, Chaushu G, Nissan J. Histomorphometrical analysis following augmentation of infected extraction sites exhibiting severe bone loss and primarily closed by intrasocket reactive soft tissue. Clin Implant Dent Relat Res. 2012 Jun;14(3):359-65. [Medline: 20491820] [doi: 10.1111/j.1708-8208.2010.00281.x] 
47. Meloni SM, Tallarico M, Lolli FM, Deledda A, Pisano M, Jovanovic SA. Postextraction socket preservation using epithelial connective tissue graft vs porcine collagen matrix. 1-year results of a randomised controlled trial. Eur J Oral Implantol. 2015 Spring;8(1):39-48. [Medline: 25738178]

48. Juodzbalys G, Wang HL. Socket morphology-based treatment for implant esthetics: a pilot study. Int J Oral Maxillofac Implants. 2010 Sep-Oct;25(5):970-8. [Medline: 20862411]

49. Huynh-Ba G, Pjetursson BE, Sanz M, Cecchinato D, Ferrus J, Lindhe J, Lang NP. Analysis of the socket bone wall dimensions in the upper maxilla in relation to immediate implant placement. Clin Oral Implants Res. 2010 Jan;21(1): 37-42. [Medline: 20070745] [doi: 10.1111/j.1600-0501.2009.01870.x]

50. Spray JR, Black CG, Morris HF, Ochi S. The influence of bone thickness on facial marginal bone response: stage 1 placement through stage 2 uncovering. Ann Periodontol. 2000 Dec;5(1):119-28. [Medline: 11885170] [doi: 10.1902/annals.2000.5.1.119]

51. Buser D, Chappuis V, Belser UC, Chen S. Implant placement post extraction in esthetic single tooth sites: when immediate, when early, when late? Periodontol 2000. 2017 Feb;73(1):84-102. [Medline: 28000278] [doi: 10.1111/prd.12170]

52. Nevins M, Camelo M, De Paoli S, Friedland B, Schenk RK, Parma-Benfenati S, Simion M, Tinti C, Wagenberg B. A study of the fate of the buccal wall of extraction sockets of teeth with prominent roots. Int $\mathrm{J}$ Periodontics Restorative Dent. 2006 Feb;26(1):19-29. [Medline: 16515093]

53. Jung RE, Sapata VM, Hämmerle CHF, Wu H, Hu XL, Lin Y. Combined use of xenogeneic bone substitute material covered with a native bilayer collagen membrane for alveolar ridge preservation: A randomized controlled clinical trial. Clin Oral Implants Res. 2018 May;29(5):522-529. [Medline: 29607553] [doi: 10.1111/clr.13149]

54. Givol N, Chaushu G, Halamish-Shani T, Taicher S. Emergency tracheostomy following life-threatening hemorrhage in the floor of the mouth during immediate implant placement in the mandibular canine region. J Periodontol. 2000 Dec;71(12):1893-5. [Medline: 11156047] [doi: 10.1902/jop.2000.71.12.1893]

55. Gray CF, Redpath TW, Smith FW, Staff RT. Advanced imaging: Magnetic resonance imaging in implant dentistry. Clin Oral Implants Res. 2003 Feb;14(1):18-27. [Medline: 12562361] [doi: 10.1034/j.1600-0501.2003.140103.x]

56. Mehra A, Pai KM. Evaluation of dimensional accuracy of panoramic cross-sectional tomography, its ability to identify the inferior alveolar canal, and its impact on estimation of appropriate implant dimensions in the mandibular posterior region. Clin Implant Dent Relat Res. 2012 Mar;14(1):100-11. [Medline: 19673959] [doi: 10.1111/j.1708-8208.2009.00226.x]

57. Rosenquist B, Grenthe B. Immediate placement of implants into extraction sockets: implant survival. Int J Oral Maxillofac Implants. 1996 Mar-Apr;11(2):205-9. [Medline: 8666452] [doi: 10.1097/00008505-199600540-00032]

58. Quirynen M, Gijbels F, Jacobs R. An infected jawbone site compromising successful osseointegration. Periodontol 2000. 2003;33:129-44. [Medline: 12950847] [doi: 10.1046/j.0906-6713.2002.03311.x]

59. Lindeboom JA, Tjiook Y, Kroon FH. Immediate placement of implants in periapical infected sites: a prospective randomized study in 50 patients. Oral Surg Oral Med Oral Pathol Oral Radiol Endod. 2006 Jun;101(6):705-10. [Medline: 16731387] [doi: 10.1016/j.tripleo.2005.08.022]

60. Siegenthaler DW, Jung RE, Holderegger C, Roos M, Hämmerle CH. Replacement of teeth exhibiting periapical pathology by immediate implants: a prospective, controlled clinical trial. Clin Oral Implants Res. 2007 Dec;18(6):727-37. [Medline: 17888019] [doi: 10.1111/j.1600-0501.2007.01411.x]

61. Del Fabbro M, Boggian C, Taschieri S. Immediate implant placement into fresh extraction sites with chronic periapical pathologic features combined with plasma rich in growth factors: preliminary results of single-cohort study. J Oral Maxillofac Surg. 2009 Nov;67(11):2476-84. [Medline: 19837321] [doi: 10.1016/j.joms.2009.04.063]

62. Kim JJ, Ben Amara H, Schwarz F, Kim HY, Lee JW, Wikesjö UME, Koo KT. Is ridge preservation/augmentation at periodontally compromised extraction sockets safe? A retrospective study. J Clin Periodontol. 2017 Oct;44(10): 1051-1058. [Medline: 28643883] [doi: 10.1111/jepe.12764]

63. Shea JJ. Morphologic characteristics of the sinuses. Arch Otolaryngol. 1936 April;23(4):484-7. [doi: 10.1001/archotol.1936.00640040493011]

64. El Zahwy M, Awad S, Kamel HM, Mostafa B. Clinical and Radiographic Evaluation of Dental implants Penetrating the Maxillary Sinus. J Inter Dent Med Res. 2017 Jan; 10(2):207-13. [URL: http://www.jidmr.com]

65. Hong YH, Mun SK. A case of massive maxillary sinus bleeding after dental implant. Int J Oral Maxillofac Surg. 2011 Jul;40(7):758-60. [Medline: 21377328] [doi: 10.1016/j.ijom.2010.11.027]

66. Hunter WL 4th, Bradrick JP, Houser SM, Patel JB, Sawady J. Maxillary sinusitis resulting from ostium plugging by dislodged bone graft: case report. J Oral Maxillofac Surg. 2009 Jul;67(7):1495-8. [Medline: 19531423] [doi: 10.1016/i.joms.2009.03.033]

67. Kumar DS, Jayakumar ND, Padmalatha O, Sankari M, Varghese SS. Effect of maxillary sinus floor augmentation without bone grafts. J Pharm Bioallied Sci. 2013 Jul;5(3):176-83. [Medline: 24082693] [PMC free article: 3778586] [doi: 10.4103/0975-7406.116795]

68. Al-Askar M, O’Neill R, Stark PC, Griffin T, Javed F, Al-Hezaimi K. Effect of single and contiguous teeth extractions on alveolar bone remodeling: a study in dogs. Clin Implant Dent Relat Res. 2013 Aug;15(4):569-75. [Medline: 22172048] [doi: $10.4103 / 0975-7406.116795$ ] 


\section{To cite this article:}

Juodzbalys G, Stumbras A, Goyushov S, Duruel O, Tözüm TF.

Morphological Classification of Extraction Sockets and Clinical Decision Tree for Socket Preservation/Augmentation after Tooth Extraction: a Systematic Review

J Oral Maxillofac Res 2019;10(3):e3

URL: http://www.ejomr.org/JOMR/archives/2019/3/e3/v10n3e3.pdf

doi: $\underline{10.5037 / \text { jomr.2019.10303 }}$

Copyright (C) Juodzbalys G, Stumbras A, Goyushov S, Duruel O, Tözüm TF. Published in the JOURNAL OF ORAL \& MAXILLOFACIAL RESEARCH (http://www.ejomr.org), 5 September 2019.

This is an open-access article, first published in the JOURNAL OF ORAL \& MAXILLOFACIAL RESEARCH, distributed under the terms of the Creative Commons Attribution-Noncommercial-No Derivative Works 3.0 Unported License, which permits unrestricted non-commercial use, distribution, and reproduction in any medium, provided the original work and is properly cited. The copyright, license information and link to the original publication on (http://www.ejomr.org) must be included. 